\title{
Multivariate Analysis Of Foreign Direct Investment In China
}

Tyler T. Yu, (tyu@ggc.usg.edu), Mercer University Miranda M. Zhang, (Zhang_mm@mercer.edu), Mercer University

\begin{abstract}
The purpose of this paper is to empirically examine the foreign direct investment (FDI) in China. China has become an increasingly important hosting economy for FDI and this trend is expected to continue with the country's entry to the World Trade organization. In this paper, we will review the current literature related to FDI, and use secondary data to employ regression to estimate the trend line of FDI in China. This is followed by factor analysis to examine the variables and factors influencing the FDI in China. We will then perform clustering analysis to look at the regional distribution of FDI in China and finally draw conclusions.
\end{abstract}

\section{INTRODUCTION}

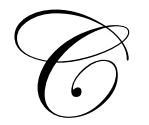

hina initiated its new economic policies in the late 1970s. Endogenously, it has allowed private businesses to start, develop, and grow and today they have become a dominant economic force with productive and economic efficiency. Exogenously, it has adopted an "Open Door" economic policy, which opens China to the rest of the world. As a result of these policies, the domestic economy has grown at a rapid rate (8-15\% annually) and its GDP has become the $7^{\text {th }}$ largest in the world (IMF, 2002). In terms of foreign economic relations, China has not only become the $7^{\text {th }}$ largest exporting country in the world (Ewing, 2001), but also the largest hosting country for foreign direct investment, surpassing the United States (IMF 2002).

Foreign direct investment is one of the biggest tools for international economic integrations. Firms view overseas expansion as a necessary step to achieve a more effective access in the markets where they presently have low representation. Investments often lead to increased trade flows indicating that trade flows and investments are complementary.

\section{PURPOSE AND OBJECTIVES}

In the past quarter of a century, China has become an increasingly important hosting economy for FDI and this trend is expected to continue with the country's entry to the World Trade organization. The purpose of this paper is to empirically examine the foreign direct investment (FDI) in China. We will first review the current literature related to foreign direct investment. Then, using secondary data, regression will be employed to estimate the trend line of FDI in China. This is followed by an application of factor analysis to examine the variables and factors influencing the FDI in China, such as GDP, Exports, and others. Using the same set of variables, we will then perform clustering analysis to look at the regional distribution of foreign direct investment in China. Finally, some conclusions may be drawn based on the empirical results.

\section{REVIEW OF LITERATURE}

Using a vector autoregression (VAR) approach, Shan (2002) conducted an empirical study on the impacts of FDI on the Chinese economy. Based on the quarterly data collected for the period 1986:1-1998:4, the empirical results show that both GDP and FDI affect each other. Second, the impact of GDP growth on FDI is greater than the impact of FDI on GDP. Third, the geographical choice of FDI in China is important. Finally, FDI in China is affected by a set of 
socioeconomic variables, ranging from international trade to wage rates.

Witherell (1997) conducted a study to examine the development of international rules for foreign investment from the OECD countries' perspective. The article discusses the multilateral agreement on investment (MAI) and the Organization for Economic Cooperation and Development (OECD). One of the major OECD's functions is to get member countries to agree on a legal framework for foreign direct investment rules through a free-standing treaty available to both OECD members and nonmember nations. This effort has won widespread international support. According to the author, foreign direct investment will continue to grow as further economic integration occurs. The more competitive the global environment becomes, the stronger the incentives will be for firms to invest abroad. Globalization removes the protectionist measures of the home market.

Since the early 1980 's, Japanese firms have increased their holdings in foreign countries significantly. Early trends showed a marked increase in the outsourcing of manufacturing facilities (Bayoumi and Liqworth, 1997). As Japan's manufacturing base found a home in international territories, it became evident to many Japanese firms that comparative advantage could be realized in the service sector as well. As foreign direct investment is more widely practiced by Japanese firms, its effect on Japan's balance of payments has become obvious.

Several factors appear to be contributing to the trend toward foreign direct investment for Japanese firms. First of all, many firms view FDI as a method of diversifying locations of production. Second, Japan has found it necessary to search elsewhere for many of the natural resources necessary for production. Investment in real estate has been a major portion of Japanese FDI. Next, the Japanese firms have found it economically beneficial to outsource much of its laborintensive production tasks. Furthermore, Japan has seen a rapid increase in money spent on research and development. Much of this R\&D takes place outside of the country of Japan.

As Bayoumi and Liqworth put it, economic growth in Japan has also contributed toward trends of outsourcing for Japanese firms. Typically, a depreciation of host country currency has a positive effect on FDI inflows. With this being the case, the appreciation of the Yen against many other foreign countries as of late has led to a substantial increase in FDI. Japan has actually experienced a growth in "reverse exports". This occurs when Japan imports goods that were produced in outsourced Japanese facilities. A side effect of FDI is generally a decrease in exported products for Japanese firms. Japan's FDI in the United States continues to grow, as does FDI with other Asian countries.

For the past fifteen years, direct investment has increased in the United States. This investment has been dominated by a few nations, namely, the U.K., Germany, and Japan. This allows for analysis in the industry motivations for the firms to invest across national borders. A study conducted by Anand and Kogut (1997) is one of the analyses.

Most of the foreign investment is in manufacturing assets, chemical industry, automotive industry, and R \& D firms. The U.S. market is influenced by foreign competition that reflects the strengths of the national origins of companies. There is however, a strong bias towards the technological sectors like electronics, capital equipment and chemicals. Market richness seems to be the pervasive evidence for the pull of American technological resources that explains the rise in direct investment in the United States.

Kasoff (1997) made a case study of Canadian direct investment in Ohio. The article discusses the reasons for Canadian Direct Investment (CDI) in the state of Ohio in the United States. The behavior represents that small manufacturing firms from Canada have a tendency to acquire existing businesses within the state of Ohio. The article speaks of the push and pull factors in foreign direct investment in Ohio. The article concludes that the leading factors affecting the likelihood of Canadian direct investment in Ohio are the nature of the industry, the closeness of the parent firm and the size of the firm.

As a result of the study, pull factors are found in the U.S. market that attracts foreign direct investment and push factors are found in the Canadian market that push foreign direct investment into the United States. Canadian firms like the large U.S. market that provides opportunities for their sales growth. Avoidance of tariff barriers is also a significant pull factor. Firm-specific assets are cited as another reason as small firms have advantages of patent ownership, resource 
availability, technology, access to capital, superior management and product differentiation.

\section{DATA AND MODELS}

\section{Data}

Secondary data were collected from statistical publications, mainly, CHINA STATISTICAL YEARBOOK, 2002 Edition, published by China Statistics Press. Cross sectional data were collected for the 31 provinces and special districts in China for the selected variables. Also, time-series data were collected for FDI in China through the period of 1984 to 2001. The year 1984 was used as the beginning of the time series because that was the year meaning data for FDI were available and collected in China.

\section{Models}

Time-Series Trend Projection

A time-series trend analysis was performed using secondary data (1984 to 1998) to predict the general trend of FDI in China. On having experimented with different mathematical/functional forms using SPSS, the linear and cubic forms appear to be the best candidates for the task of curve-fitting. Specifically, the trend line was estimated using the following equations:

FDI $=\square \boldsymbol{\alpha}+\boldsymbol{\beta} \square$ Time $+\square \square \square \square \square \square \square \boldsymbol{\varepsilon}$ and

FDI $=\square \boldsymbol{\alpha}+\square \boldsymbol{\beta}_{1}$ Time $+\boldsymbol{\beta} \square_{2}(\text { Time })^{2}+\square \boldsymbol{\beta}_{3}(\text { Time })^{3}+\boldsymbol{\varepsilon}$

Where

- $\quad$ FDI is the foreign direct investment in China, measured in US\$

- $\quad$ Time is the independent variable predicting FDI over time,

- $\quad \boldsymbol{\alpha}$ and $\boldsymbol{\beta}$ are constant and coefficient for the independent variable, Time,

- $\varepsilon$ is the error term.

Theoretically, it is expected that FDI and Time have a positive relationship. That is, as time passes on, foreign direct investment will increase. The empirical result of the estimation is reported in Table 1.

As shown in Table 1, both equations have a significant $\mathrm{F}$ ratio, meaning that the independent variable, Time, is a good indicator of FDI in China. The sign of the coefficient is positive, indicating that there is a positive relationship between FDI and Time. The magnitude of the coefficient is 37.81, indicating how much FDI will increase from one year to another. The $\mathrm{R}^{2}$ of the linear function is 0.85 , an indication that $85 \%$ of the variation in FDI can be explained by the model. The $\mathrm{R}^{2}$ of the cubic function is even higher, i.e., $95 \%$, which again indicates a better fitting of the curve and a higher percentage of the variation in FDI that can be explained by the model. Finally, the fitted curves are depicted in Figure 1. Graphically, the cubic seems to have a better match with the original data plot.

Table 1

Trend Line Estimation Of FDI, Linear And Cubic Forms

\begin{tabular}{|c|c|c|c|c|c|c|c|c|c|}
\hline Dependent ariable & Math Form & $\boldsymbol{R}^{\mathbf{2}}$ & $\boldsymbol{d} . \boldsymbol{f}$. & $\boldsymbol{F}$ & Sig. $\boldsymbol{F}$ & $\boldsymbol{\alpha}$ & $\boldsymbol{\beta}_{\boldsymbol{1}}$ & $\boldsymbol{\beta}_{\boldsymbol{2}}$ & $\boldsymbol{\beta}_{\boldsymbol{3}}$ \\
\hline FDI & LIN & .85 & 13 & 73.59 & .000 & -126.58 & 37.81 & & \\
\hline FDI & CUB & .95 & 11 & 76.17 & .000 & 118.58 & -80.45 & 13.6 & -.44 \\
\hline
\end{tabular}


Figure 1

\section{Curves Fitted For FDI In China}

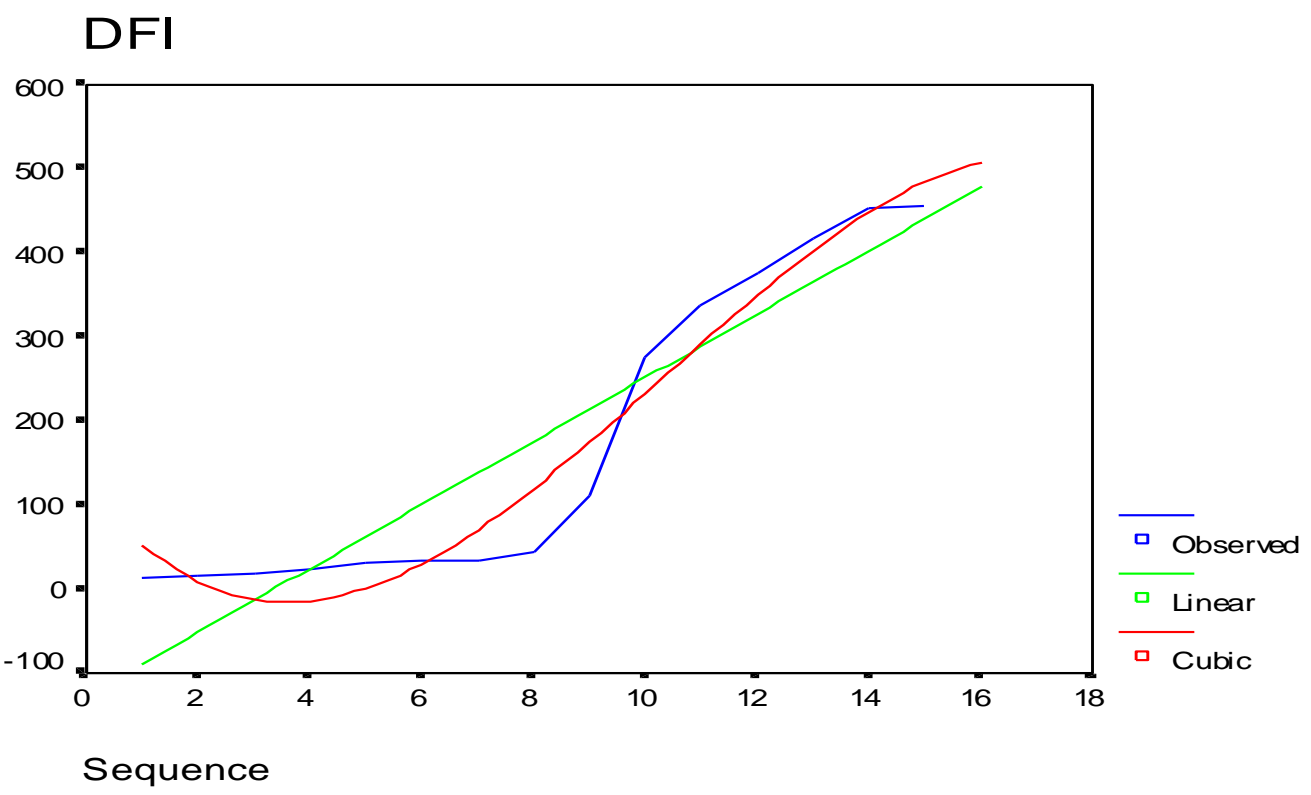

Factor Analysis

There are many variables that may have an impact on FDI. In this study, we selected the following variables that we believe to have impact on FDI in China. These variables are:

$\mathrm{X} 1 \rightarrow$ Total Export and Import

$\mathrm{X} 2 \rightarrow \quad$ GDP in US\$ (100 million yuan, $\$ 1=¥ 8.30)$

$\mathrm{X} 3 \rightarrow$ Number of Hotels

$\mathrm{X} 4 \rightarrow$ Number of Foreign Tourists

$\mathrm{X} 5 \rightarrow$ Number of Institutes of Higher learning

$\mathrm{X} 6 \rightarrow$ Number of High School Graduates

$\mathrm{X} 7 \rightarrow$ Length of Railways in Operation

$\mathrm{X} 8 \rightarrow$ Total Length of Express way and Class I to IV Highway

$\mathrm{X} 9 \rightarrow \quad$ Number of local phone Subscribers $(10,000)$

$\mathrm{X} 10 \rightarrow$ Number of Mobile phone Subscribers $(10,000)$

$\mathrm{X} 11 \rightarrow$ Number of Subscribers of E-mail service and Internet Service

Factor Analysis technique was applied to the selected socioeconomic variables. The primary purpose of factor analysis is to describe, if possible, the covariance (or correlation) relationships among many variables in terms of a few underlying, but unobservable random quantities called factors. As such, the variables grouped into one factor are closely correlated among themselves, but not so closely correlated with variables grouped into different factors (Johnson and Wichern, 1998). SPSS was used to apply factor analysis and the results were reported in the following tables.

As shown in Table 2, Total Variance Explained (the unrotated solution), the percentage of the total variance in the 11 standardized variables explained by the first common factor is $51.2 \%$, the percentage of the total variance in the 11 standardized variables explained by he second common factor is $18.63 \%$, and the percentage of the total variance in the 11 standardized variables explained by the two common factors combined is 69.83 percent. In the rotated solution, as shown in Table 3, Total Variance Explained (the rotated solution), the percentage of the total variance in the 11 standardized 
variables explained by the first common factor is $40.77 \%$, the percentage of the total variance in the 11 standardized variables explained by the second common factor is $29.05 \%$, and the percentage of the total variance in the 11 standardized variables explained by the two common factors combined is 69.83 percent.

Table 2

Total Variance Explained (The Un-Rotated Solution)

\begin{tabular}{|c|c|c|c|}
\hline & \multicolumn{2}{|c|}{ Extraction Sums of Squared Loadings } \\
\hline Import and Export & $\begin{array}{c}\text { Total } \\
\text { (eigenvalues) }\end{array}$ & \% of Variance & $\begin{array}{c}\text { Cumulative } \\
\text { Variance\% }\end{array}$ \\
\hline GDP & 5.63 & 51.20 & 51.20 \\
\hline Number of Tourists & 2.05 & 18.63 & 69.83 \\
\hline Number of Hotels & 0.99 & 9.06 & 78.88 \\
\hline Number of Colleges & 0.85 & 7.69 & 93.57 \\
\hline High School Graduates & 0.77 & 7.00 & 96.04 \\
\hline Length of Railroad (km) & 0.27 & 2.46 & 97.64 \\
\hline Length of Highways (km) & 0.18 & 1.60 & 98.94 \\
\hline Number of Local phones & 0.14 & 1.30 & 99.62 \\
\hline Number of Cell phones & 0.07 & 0.68 & 99.90 \\
\hline Internet Subscribers & 0.03 & 0.28 & 100.0 \\
\hline Extraction Method: Principal Component Analysis & 0.01 & \\
\hline
\end{tabular}

Table 3

Rotated Component Matrix

\begin{tabular}{|c|c|c|c|}
\hline & \multicolumn{2}{|c|}{ Rotation Sums of Squared Loadings } \\
\hline & $\begin{array}{c}\text { Total } \\
\text { (eigenvalues) }\end{array}$ & \% of Variance & Cumulative Variance\% \\
\hline Import and Export & 4.49 & 40.77 & 40.77 \\
\hline GDP & 3.17 & 29.05 & \\
\hline Number of Tourists & & & \\
\hline Number of Hotels & & & \\
\hline Number of Colleges & & & \\
\hline High School Graduates & & & \\
\hline Length of Railroad (km) & & & \\
\hline Length of Highways (km) & & & \\
\hline Number of Local phones & & & \\
\hline Number of Cell phones & & & \\
\hline Internet Subscribers & & & \\
\hline Extraction Method: Principal Component Analysis & & \\
\hline
\end{tabular}

The percentages of total variance in the 11 variables (in both unrotated and rotated solutions) explained by the two common factors combined are shown in Table 4 Communalities. For example, $90.2 \%$ of the variance in GDP is explained by the two common factors combined, which implies that $9.8 \%$ of the variance in GDP is due to the factor specific to GDP. 
Table 4

Communalities

\begin{tabular}{|c|c|c|}
\hline & Initial & Extraction \\
\hline Import and Export & 1.00 & 0.838 \\
\hline GDP & 1.00 & 0.902 \\
\hline Number of Tourists & 1.00 & 0.674 \\
\hline Number of Hotels & 1.00 & 0.812 \\
\hline Number of Colleges & 1.00 & 0.604 \\
\hline High School Graduates & 1.00 & 0.693 \\
\hline Length of Railroad (km) & 1.00 & 0.649 \\
\hline Length of Highways (km) & 1.00 & 0.637 \\
\hline Number of Local phones & 1.00 & 0.946 \\
\hline Number of Cell phones & 1.00 & $3.515 \mathrm{E}-02$ \\
\hline Internet Subscribers & 1.00 & 0.890 \\
\hline Extraction Method: Principal Component Analysis
\end{tabular}

Neither the unrotated nor the rotated has a simple matrix. Based on Principal Component Analysis (Extraction Method) and Varimax with Kaiser Normalization (Rotation Method), there are two common factors identified. The two factors appear to be:

Factor $1=$ Link/Contact with the rest of the World; and Factor $2=$ Infra-structural Development. The two factors are reported as follows:

Factor $1=$

$0.904($ Exp\&Imp $)+0.651($ GDP $)+0.821$ (Tourist $)+0.834($ Hotels $)+0.412$ (Colleges $)-0.477$ (Rail km) $+0.762($ Local Phone) +0.921 (Internet Subscribers)

Factor $2=$

$0.692(\mathrm{GDP})+0.659($ Colleges $)+0.811($ High School $)+0.477($ Rail km $)+0.796($ Hwy km $)+0.604($ Local Phone $)$

The top three variables having the highest correlation with the first common factor are Internet Subscribers, International trade, and Hotels; The top three variables having the highest correlation with the second common factor are High School Graduates, Highways, and GDP. Using Johnson and Wichern (1998)'s simple method for calculating common factor scores, Factor 1 and Factor 2 scores for each of the 31 provinces were computed using SPSS (and appended to the data file). The top two provinces having the highest factor1 scores are Guangdon (18.25) and its distance second Jingsu (7.80). The top two provinces having the highest factor2 scores are Guangdon (6.49) and Shandong (5.89).

\section{Clustering Analysis}

China is a developing country with uneven distribution of income and imbalanced economic growth and development. Some regions in China may have already been at par with or close to the status of economic development found in developed countries, while other regions may be among the poorest, most underdeveloped in the world. Theoretically, This may have been reflected in these regions' ability to attract FDI.

Clustering analysis, also known by the names of segmentation analysis and taxonomy analysis, refers to a set of techniques used to partition a collection of entities into relatively homogeneous groups or "clusters" so that there is a high similarity between the entities within each cluster, yet low similarity between entities in different clusters (Johnson \& Wichern, 1998). In this study, the K-Means clustering method is applied to the selected variables for the 31Chinese provinces and special districts. 
We first group the 31 provinces and special districts based on their previous records of hosting FDI, i.e., the 31 provinces were ranked in ascending order. Then, the same group was also categorized into four categories (A, B, C, D) based on the perceived status of economic development, which is classified mainly according to the provincial GDP. For example, Category A includes the provinces and special districts where economic reform has been more successful. Examples of category A are Guangdon, Shanghai, and Beijing. Category D, on the other hand, consists of the most underdeveloped provinces in China, mostly in-land provinces where economic reform has not been very drastic and therefore is still very primitive. Tibet, Gansu and Qinghai belong to this category. The hypotheses of the clustering analysis are:

Ho: $\quad$ There is a high degree of similarity between group ranking of the provinces based on FDI and perceived economic development and the clustering of them based on the clustering analysis

Ha: $\quad$ The Ho is not true.

When the K-Means clustering method was applied to the variables selected for the study, four clusters were generated. The empirical result of the clustering analysis is reported in Table 5.

Table 5

Result Of Clustering Analysis

\begin{tabular}{|c|c|c|c|}
\hline Cluster 1 & Cluster 2 & Cluster 3 & Cluster 4 \\
\hline \multirow{15}{*}{ Guangdon(1) (A) } & Beijing (16) (A) & Shanghai (11) (A) & Hebei (2) (B) \\
\hline & Tianjin (17) (A) & Jiangsu (5) (A) & Shanxi (13) (C) \\
\hline & Jilin (23) B) & & Inner Mongolia $(25)(\mathrm{C})$ \\
\hline & Anhui (12)(B) & & Liaoning (15) (B) \\
\hline & Jiangxi (7)(B) & & Heilongjiang (22) (B) \\
\hline & Hainan (4) (A) & & Zhejiang (20) (A) \\
\hline & Chongqing (8)(B) & & Fujian (9) (A) \\
\hline & Guizhou (26) ( C ) & & Shandong (14) (A) \\
\hline & Tibet (31) (D) & & Henan (6) (B) \\
\hline & Gansu (27) (D) & & Hubei (2) (B) \\
\hline & Qinghai (30) (D) & & Hunan (3) (B) \\
\hline & Ningxia (29) (D) & & Guangxi (21) (B) \\
\hline & Xinjiang (26) & & Sichuan (10) \\
\hline & & & Yunnan (18) \\
\hline & & & Shanxi (13) \\
\hline
\end{tabular}

As shown in the table, the four clusters generated and listed are Clusters 1, 2, 3, and 4. What are also reported in the table are the group rankings of FDI status of each province and its perceived status of economic development based primarily on the GDP indicator. The study reveals a certain degree of consistency between the clusters generated in the study and the rankings of FDI as well as the perceived status of economic development. For example, Guangdon province has a cluster all by itself. This is consistent with its first place in hosting FDI and its perceived economic development. The province was among the very first few provinces pioneered China's economic reform in the late 1970s. Cluster 2 consists of either the less developed provinces, which also have a lower level of FDI, or the special districts such as Beijing, Tianjin and Hainun, which are generally speaking much smaller than the regular Chinese provinces yet are more developed. Shanghai and Jiangsu, the province adjacent to it, are in the same cluster. This is consistent with reality. Those two were among the first to start their economic reform and both have been very successful with their course of economic development and growth. The last cluster has mainly the middle to upper middle classes of FDI as well as economic development. So, overall, the null hypothesis can be confirmed by the study. 


\section{CONCLUSIONS}

\section{Summary Of Empirical Results}

In this study, foreign direct investment in China was examined. Specifically, a trend analysis was conducted to estimate an equation that could be used to predict the FDI in China in the future. According to the linear equation, the FDI forecasts for 1999 and 2000 are $\$ 478.32$ and $\$ 516.13$. The actual FDI in China in those two years are $\$ 403.19$ and $\$ 407.15$, respectively. The cubic equation projected FDI in China to be $\$ 508.25$ and $\$ 532.17$, respectively.

The factor analysis yields two factors: Factor $1=$ Link/Contact with the rest of the World; and Factor2 = Infra structural Development. Using the variant of Johnson and Wichern's simple method for calculating common factor scores, Factor 1 and Factor 2 scores for each of the 31 provinces were computed using SPSS (and appended to the data file). The top two provinces having the highest factor 1 scores are Guangdon (18.25) and its distance second Jingsu (7.80). The top two provinces having the highest factor2 scores are Guangdon (6.49) and Shandong (5.89). This finding is relatively consistent with reality. For example, Guangdon province has the highest ranking in terms of FDI in China.

The clustering method generates four groups. These groups represent the different levels of FDI and the causes of the differences in FDI among these provinces. The empirical results reveal some insights as to the ability to attract FDI and therefore are important to investment decision makers regarding future investment. For example, Guangdong Province has the highest level of foreign direct investment unparalleled by any other provinces. Shanghai and Jiangsu are not only adjacent to each other, but also have similar socioeconomic development status. Overall, the result of the clustering analysis is consistent with the reality.

\section{Suggestions For Future Research}

It will be a challenge of future research to apply Discriminant Analysis to further analyze the data. Also, a multiple regression model may be constructed by using Principal Component scores.

A further examination of variables may be necessary. There may be relevant variables that have been omitted from the study. Last but not least, a more scrupulous scrutiny of the variables currently included in the study may deem beneficial.

Table 5 shows the result of the clustering analysis. As shown in the table, the four clusters generated and listed are Clusters 1, 2,3, and 4. What are also reported in the table are the group rankings of FDI status of each province and its perceived status of economic development based primarily on the GDP indicator. The study reveals a certain degree of consistency between the clusters generated in the study and the rankings of FDI as well as the perceived status of economic development. For example, Guangdon province has a cluster all by itself. This is consistent with its first place in hosting FDI and its perceived economic development. The province was among the very first few provinces pioneered China's economic reform in the late 1970s. Cluster 2 consistent of either the less developed provinces, which also have lower level of FDI, or the special districts such as Beijing, Tiajin and Hainun, which are generally speaking much smaller than the regular Chinese provinces yet are more developed. Shanghai and Jiangsu, the province adjacent to it, are in the same cluster. This is consistent with the reality.m. Those two were among the first to start their economic reform and both have been very successful with their course of economic development and growth. The last cluster has mainly the middle to upper middle classes of FDI as well as economic development. So, overall, the null hypothesis can be confirmed by the study. 


\section{REFERENCES}

1. Anand, Jaideep and Bruce Kogut, Technological Capabilities of Countries, Firm Rivalry and Foreign Direct Investment, Journal of International Business Studies, v28, n3, P.445-465, Third Quarter 1997.

2. Bayoumi, Tamim and Gabrielle Liqworth, A Japanese foreign direct investment and regional trade, Finance \& Development, v34, n3, P. 11-13, Sept. 1997.

3. Ewing, Jack, Why Germany’s Economy is Stalling Out, p. 60, Business Week, Nov. 19, 2001.

4. IMF, International Financial Statistics, Jan. and Feb. 2003.

5. Johnson, Richard A. and Dean W. Wichern, Applied Multivariate Statistical Analysis, Fourth Edition, Prentice Hall, 1998.

6. Kasoff, Mark J, Benedict, Mary Ellen, and Stacy Lauer, Canadian direct investment in the United States: An Ohio perspective, Canadian Journal of Administrative Sciences, v14, n2, P. 178-187, June 1997.

7. National Bureau of Statistics of China, China Statistical Yearbook, vol. 20, No. 20, China Statistics Press, 2001 Edition.

8. Shan, Jordan, A VAR Approach to the Economics of FDI in China, Applied Economics, v34, p.885-893, 2002.

9. Witherell, William H., Developing international rules for foreign investment: OECD's multilateral agreement on investment, Business Economics, v32, n1, p.38-43, Jan. 1997.

\section{NOTES}




\section{NOTES}

